れ社こシこうに上し注相し本的階

ア学のン爻仰

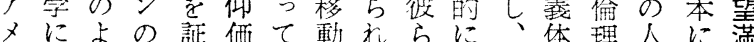

リ二う階明健、のるの事機制的々招足

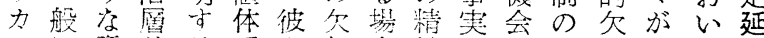

のに意差る系ら如合神でのそ陷今て期

屈み胃をのでのと唯的あ国れに早は説

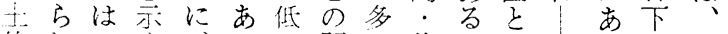

的れ八夺、るい間い倫户信、る層一

条るイデ各、地の。理メじにの階般

作もマ、種之位関例的川らあで級大

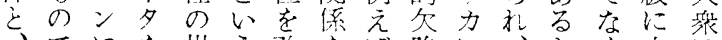

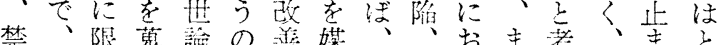

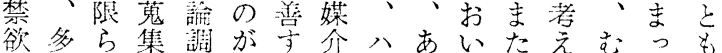

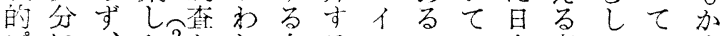

プに、た斿自るマいは本者乃いく

口広ア。らわ発导ンは、な社る

テ大メ教れ的のは彼下ぼ多会原学

スなリ龍のなは、ら層にい機因識

夕フ力的仮行、神の階比之構は者

ン口社・説動下社価級軟考の決?

トン会職でを嘚会值の卖え欠し人1

のテな業あ萎階的体上れて陷てン

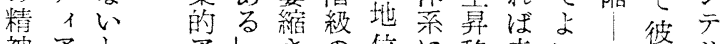

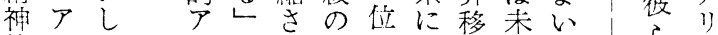

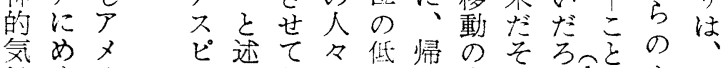

候ま゙わ力

社

動

に

関

于

る

欲

望

满

足

延

期

説

の

検

討

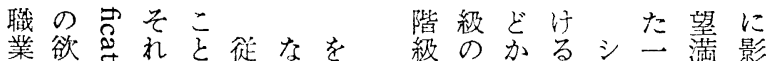
階望怘の吕順階最肉の人ら青二つ足響 層属正らの級小体価々七少ナの延さ あ性医構德の限的値はン年イ学期れ るに先﨎成を友し・体欲卜の名説説て

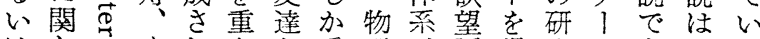

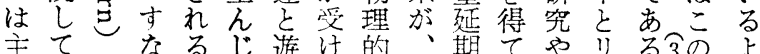

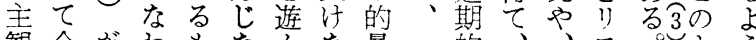
観全がわもなんな暴的、、ス吼る

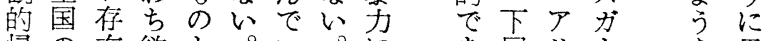
渧の在欲と。い。に層リ早な思 属高守望考親るアすする階りドする 階校る満えへかスぐ筑ンは狄

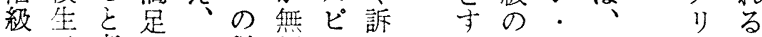

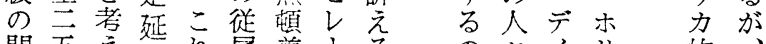
間五元期れ属着门る ですた期に期でシ 予人そパ効䦕あるョ性 想のし夕乙短。水表 通標て! 中良準出 り本、ン流い費がが 加を彼守階|的低自

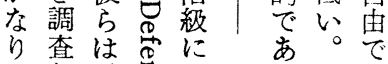
り査は害に

のし、索お

有た前』い

意亡記のて 差ら公芯 る供る 行㤎 儀ぞ椠
の々イリ

ではヴン常シ

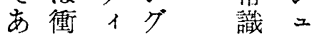
る動ススをナ 。追やへ よ随 ダッ b的 $\bar{~}$ 具で!の 体あトエ 的るのル にが黒么 は、资夕 中研ン比 下流究に示の 層階な拈欲
安 や多 队 統 的 小分 


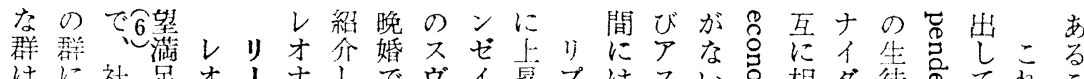
はに社足才リナしでヴイ昇プはスい号相タ徒号て机こ

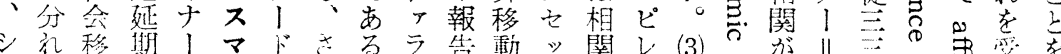

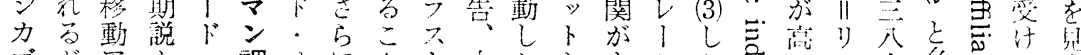

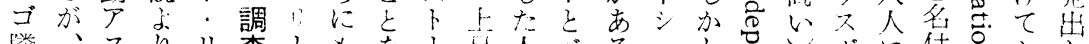

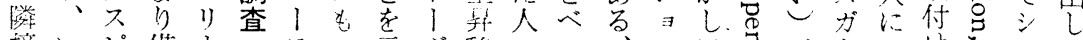

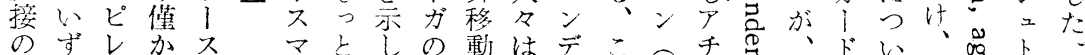

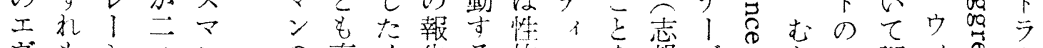

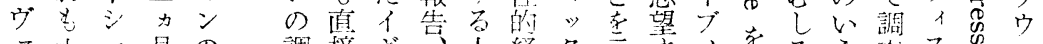

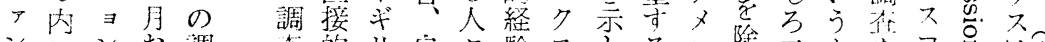

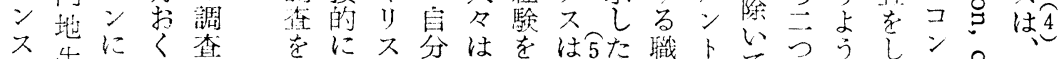

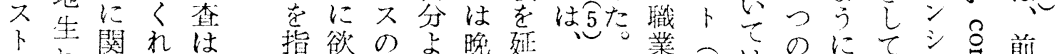

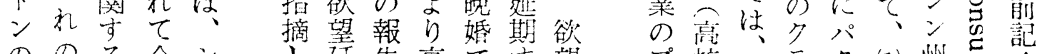

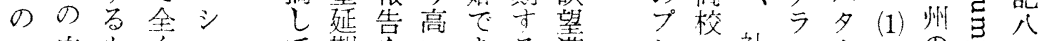

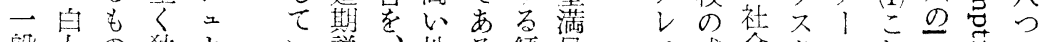

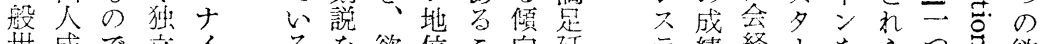
世成で立イるを欲位こ向政テ續経、をらつき欲

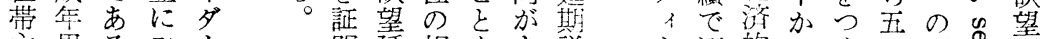

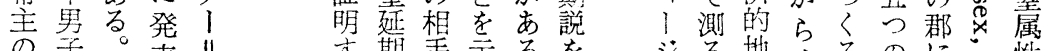
ラ尒調に表

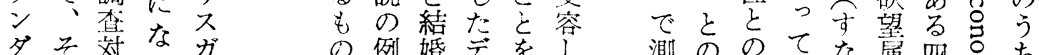
厶の象っ

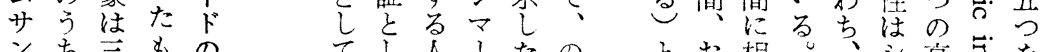

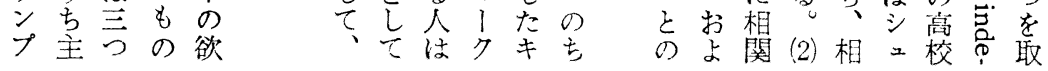

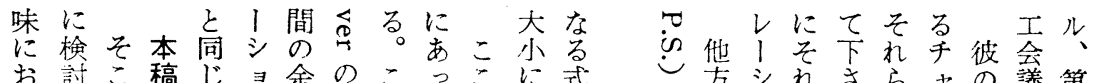
お討こ稿じョ余のこうこに式たで方シれさららの議第 いしでのでン裕方れてでよにらで、ョたいがン調所第

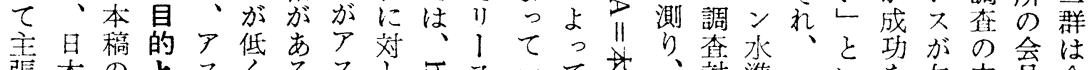

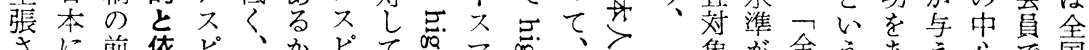

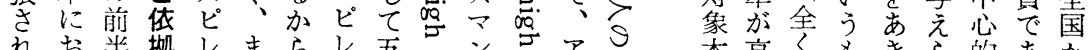

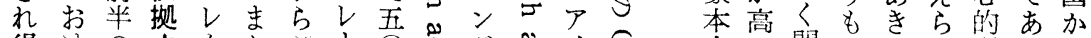

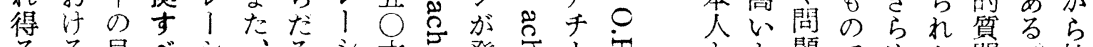

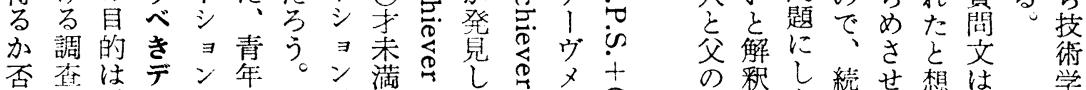

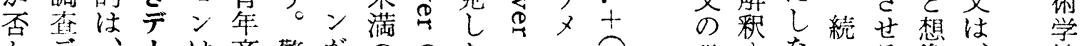

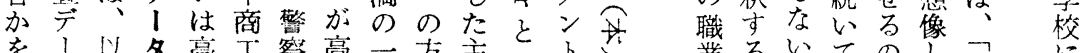

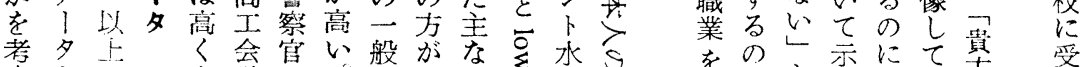

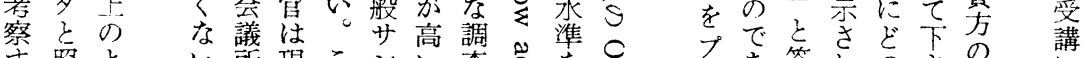

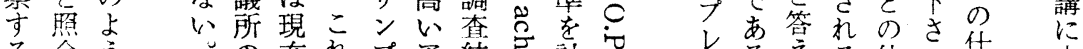
る合うの在れプア結五棓它

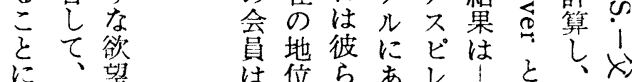

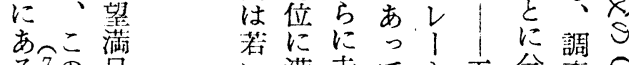

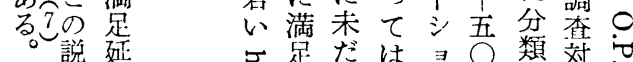
方期

何 説

らを

加内

の 在

意 的

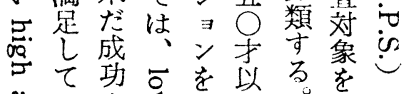

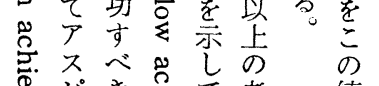
レる学る位い仕来 スるた重和事た テ者二重次の警 1 はの架の志

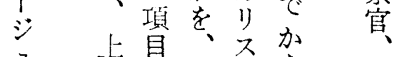
= 算目チ各な 第 ス 移第エのの各の齐 コ 動 1 表名苜成 群 ア参で自功青 ○不照示に䒚商 
第 1 表 アスピレーション水準の単純集計

$$
\text { （エヴォンストン, TAS II） }
$$

健康をおびやかす

家族と暫く別居する

国中を転居して廻る

貴方の土地を離れる

貫方の友人から遠ざかる

余睱の時間がなくなる

政治的意見を五无ない

宗教的意見を霄えない

新しいルーティンを習う

今より一層㗢く

責任がもっと重くなる

子供や家庭をはっておく

コッソリつけ届けせねばならぬ

沝宅がおてくなる

山奥八引越す

平

均

$$
\text { エヴンンストン }
$$

8.3

18.2

30.6

44.6

47.9

55.4

51.2

72.7

67.8

80.2

80.6

16.9

24.8

48.1

50.9

47.6 38.9
て問查試怘菒依 計らの験占区拠 に成主研导部守 耐る力究に在 え個と别しょ隽き 多訪て代号男 の問行表供有夕 六面な者給権は 二接わ安給者 三調れ思さを主 票查たされ罡々 ○でものる集し 六あの二。団て 九るで部ことと筆 一九専よ調し者 $\% \bigcirc ら っ$ 查た都 ○社てはサ昭 で人会、文ン和 あの移東部プ三 っサ動洋省り旮 たンに大科ン年

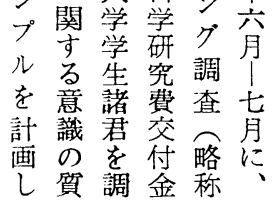

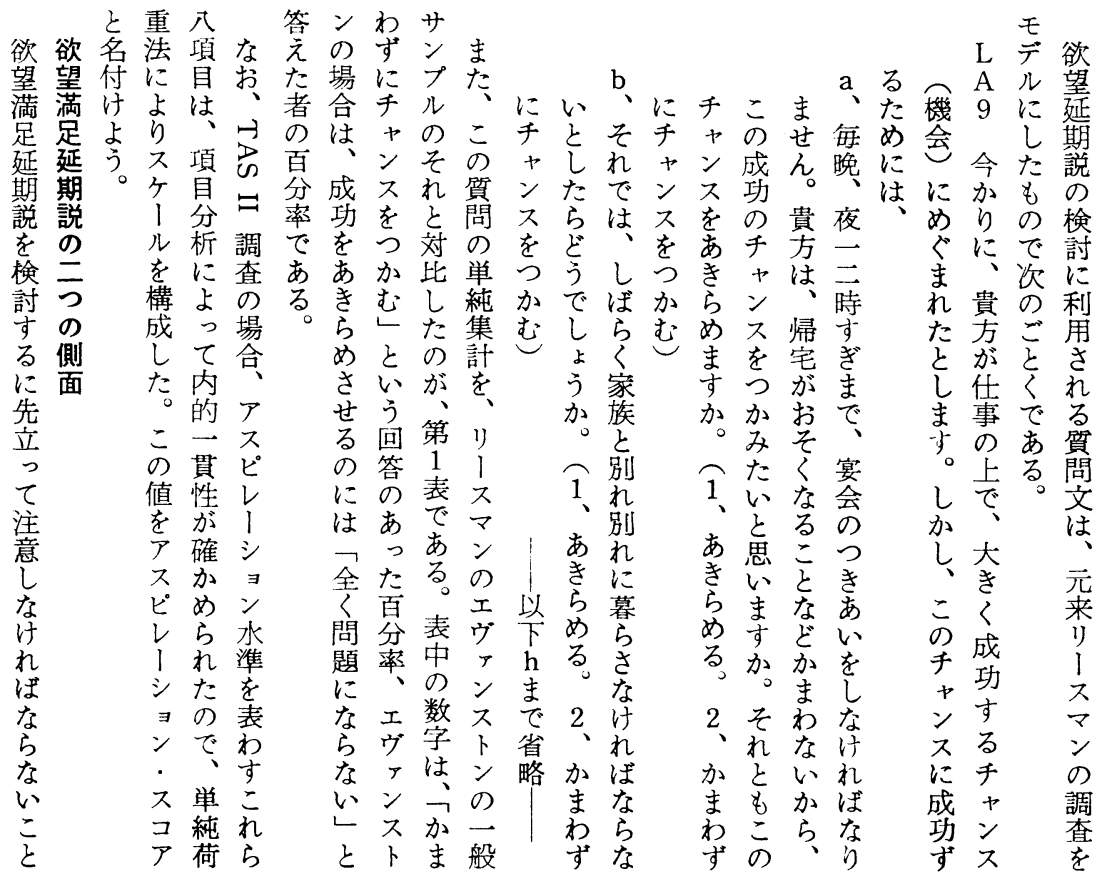




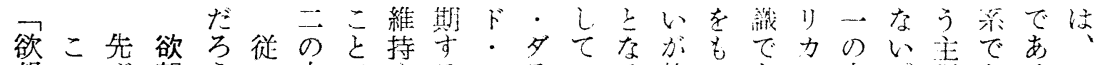

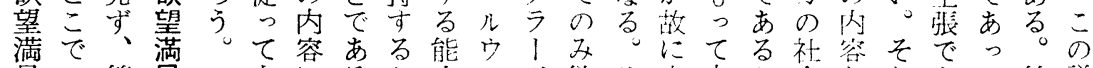
足の第足本にるた力

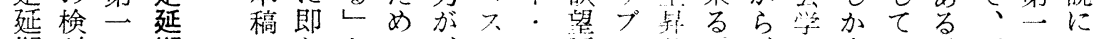
期討の期にしとに、・八然七移・、に含シ、下のは

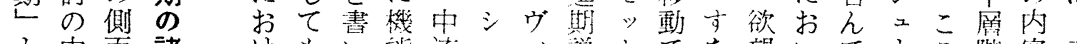
と中面諸忆もい能流ェィ説卜でな望いでナこ階容二 い心か属る、てし階ナガを川きわ満ていイに級とつ うはら性検検、て級イ、紹べなち足、な多はははの

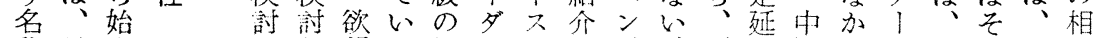
称果 め

に光光

さア

わ力

L I

W力

も市

の 流

を階

含 級

んの

で晌

る体

か系

ゔが

もし望る地 1 トしデ、下期流っ II社の欲互 、た満こ位川・てィと属説階たり会反望に

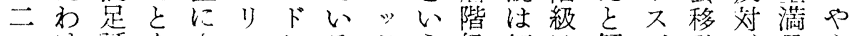
つけ延をたスレるクう級極は解力動、足や ので期示昇ガイしス主はめ移积、をす延異 内あ顶唆し、ク、は張欲て動すドのな期な

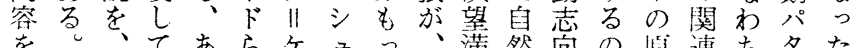
をしてあらケこっ、満然向の少連ち夕た 别第いるのイトぱ欲足に的が論は衔।内 マ 一るい研卜ラら望延、で正文值動ン容 にのこは究ンウこ延期社あしは接追がが 行内と中は. な容は流子ホも第説夕移と。橄に的流ま う階欲り、兰の丁動いし泌はで階れ 必並よ級望ンデの第ンとうかに含あ級て 要行りの満グイ内恶をうこしはまるのい がし重地足スヴ容の持なと、これ、価る

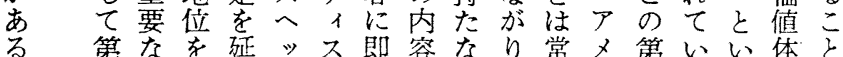

ウれが味と限様かでレシ止スな階わち考るたか スどに子ででるに。も|ここをのく級ち声察シ。諸

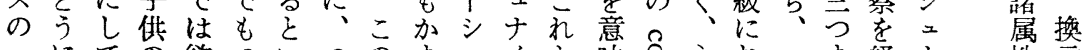

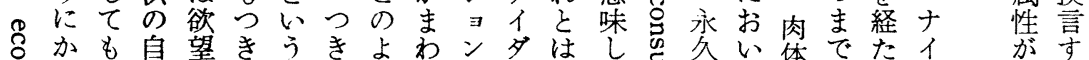

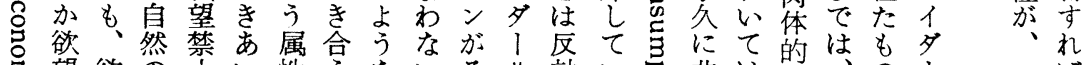

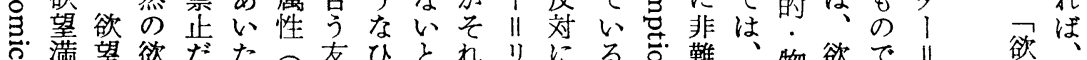

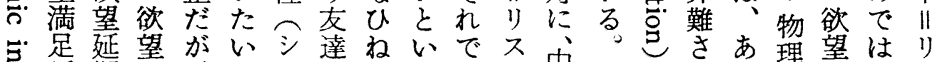

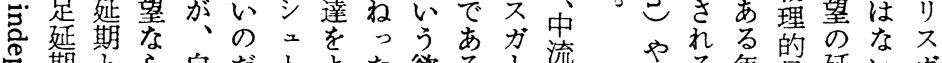

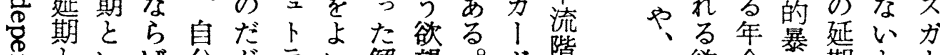
总いは分がラ心解望。階

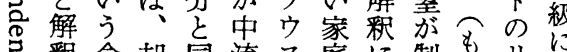
节釉念却同流又庭に制も当お

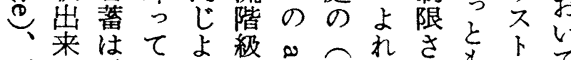

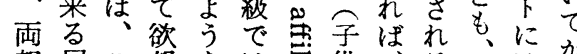
親属こ望なは总供っる、中は方 の性こ追家そ富守これる流含え

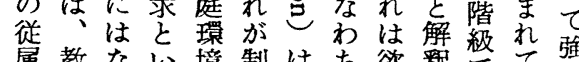
属教ない境制はち欲积でて弦

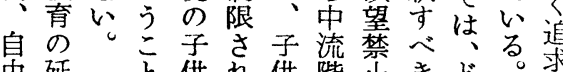

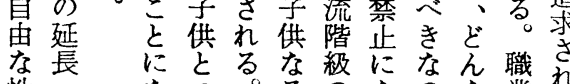
性乞なら。るのなのな業れ

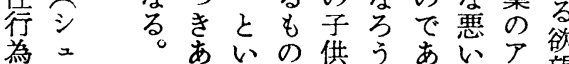

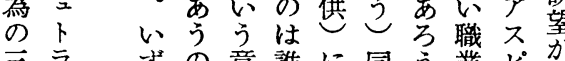
望に令力期々! ナ等達シはを方 やあたたなわ検解吕 従る。らう欲て琏秎 順同許ウ望あたさガ 、様さス学る公的 にれの禁名つるた 欲、るの禁のの 望無々品をの属のシ の䭾い合、性でュ 延遗う怘意少は省上

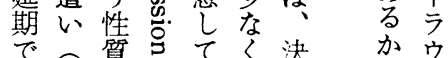
ぼき貿きてくと決㤎ウ なっもはるもて が でので中すの公に梌 禁ウは流なうな学な 


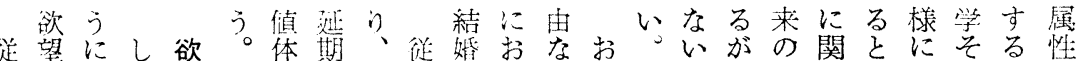

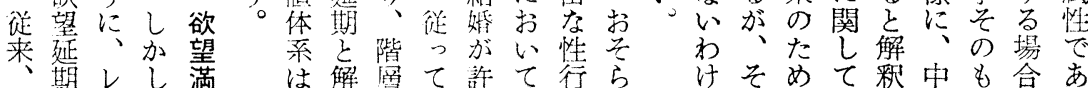

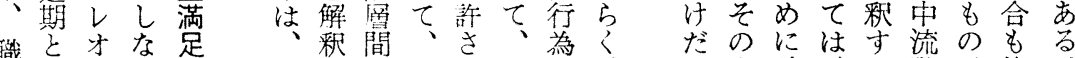

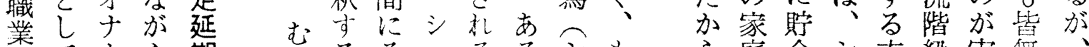

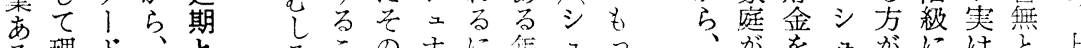

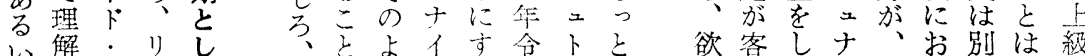

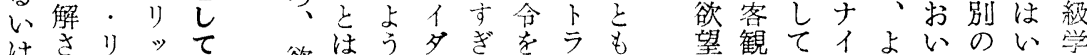

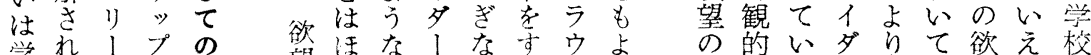

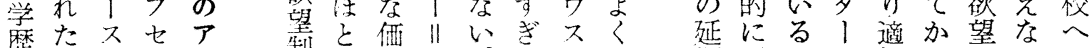
のアマッス制え值り。机の欲期経と川切えでいの

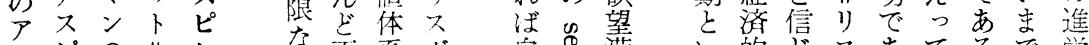

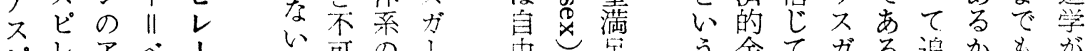

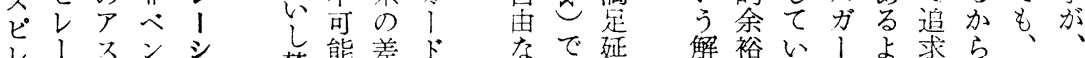

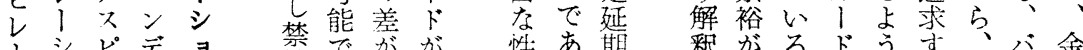

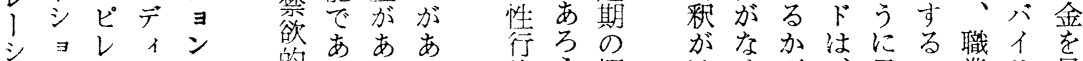

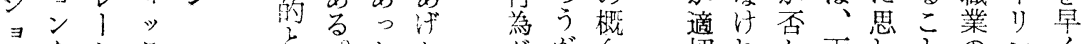
ンをシク

を問 $\exists$ ス

调題ン

查にの指

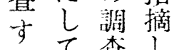

万て 湘し

場るは方名

合省当尚

たに・よ

多的た

な流乞個

し階ての

得級当属

るに、性

もみそに

のら社関

でれを市

ある欲る

万価望限
が㤎

許、が

さこ市

万壮

のて亦

注中舟

な流の

階注 切加両わ的の之 でばと親れがアの稼 あ貯いがる奖不指ぐ る金う自。励 ピ摘欲 よし質分闻さレ亭望

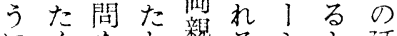
にくをち視るシる延 はて用子向欲 $\exists う$ 期 思导心供従望ンに学

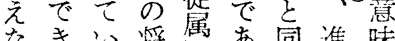
なき心将属あ同進味

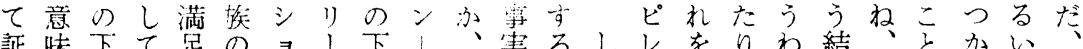

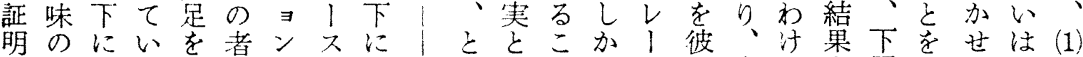
さアおるーとをマあはいしとしシらとでを覸らつど れス汁の時二测ンる、うてがわョ自級は得階画れかの るピるだ征緒定のか純こ確出れン身のなる級しるせる こレアか期にしア否粋と諗来わがが学いのでてとたう

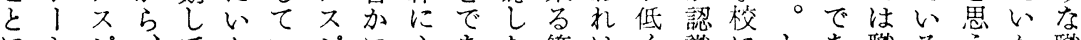
にシピ、てたいピに心あた筈はく識にしあ職るうか職 なョレこ、いるレは理る上で、なし行かる業かか方業

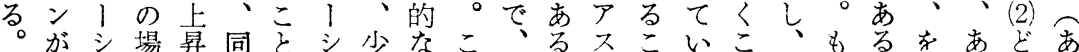

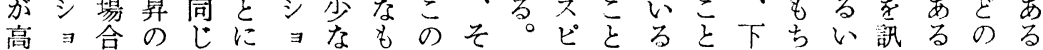
けンのチ十なンくの場れすレは限が層ろはねいよい

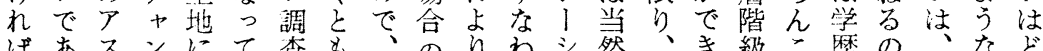

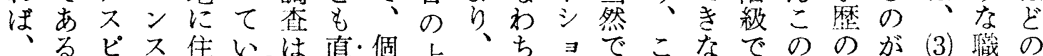

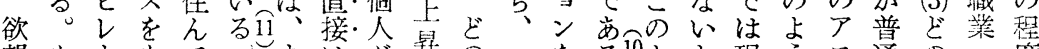

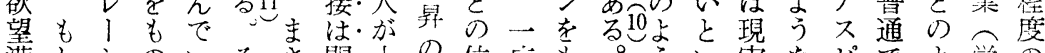
満しシのいそさ関上の位瓜占。うい実なビでよ学の 足もョにたしに係昇意、現う 延中ンすいてそしチ欲地在少 期流はる、、のな+位のし 説階、かな健よいン は級満どど康う。スア向実っ こに是うとでなレにス上のた

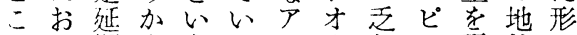
にい期をうたスナしし意位で 汢ての問欲いピ、い、図を問 じこ檥題望、レド条シ守既題 めの牲にの家1・件 ヨる定に
なう汇デレあう校学

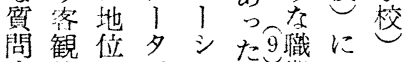
文的の隹妇籍つに で事高全ンそっけつ 光実い去がて憵るき ら唯職無低し校とた れあ業意いてし思い るりに味、おに势加

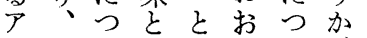
不い心い主く市 
第 2 表 階層別アスピレーション・スコア

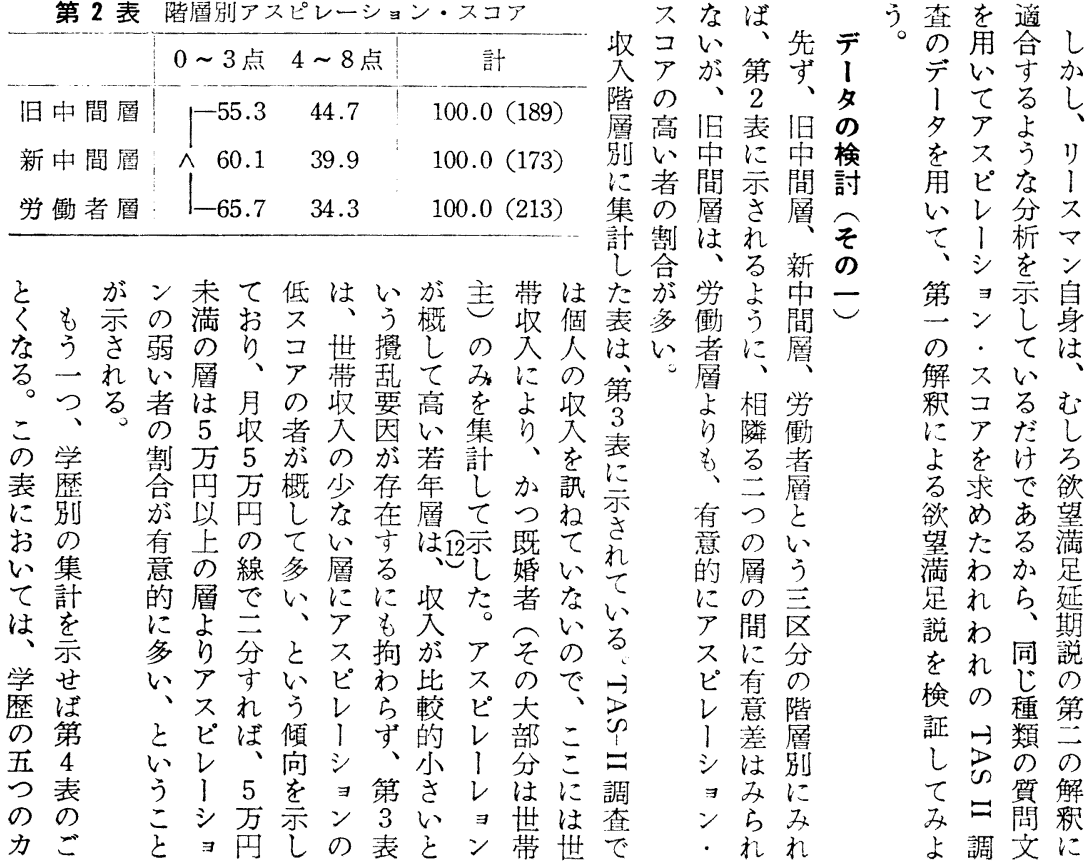

なもしけい低び字関、第 3 表世率月収別アスどレーション・スコア

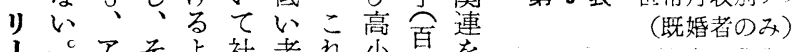

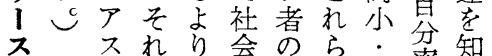

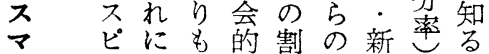

ンレも相上合表中のこ

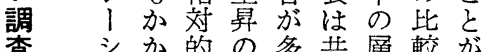

查シかか的の多共層較が

検 ンら多めな元の行き

討

の高、欲こて間なる。

高一之望望階になそ

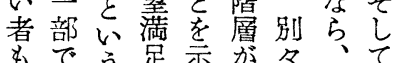

存は説超示㠰に大さ

在あ识延てへ学ら

賁る立期打行有卒に

る讨証さり意以、

これれ、礼な個

注も゙れる換ぞ差の美層の

\begin{tabular}{|c|c|c|c|}
\hline & $0 \sim 3$ 点 & $4 \sim 8$ 点 & 計 \\
\hline 2 万円未満 & 66.7 & 33.3 & $100.0(3)$ \\
\hline 2 万円以上 & 53.8 & 46.2 & 100.0 (13) \\
\hline 3 万円 " & 75.0 & 25.0 & $100.0(52)$ \\
\hline 4 万円 $"$ & 75.9 & 24.1 & $100.0(58)$ \\
\hline 5 万円 $"$ & 65.0 & 35.0 & $100.0(117)$ \\
\hline 7 万円 $"$ & 58.6 & 41.4 & $100.0(58)$ \\
\hline 10万円 " & 62.9 & 37.1 & $100.0(62)$ \\
\hline 15万円 $" 1$ & 50.0 & 50.0 & $100.0(22)$ \\
\hline 20万円 ＂ & 34.5 & 65.5 & $100.0(30)$ \\
\hline 5 万円未満 & 73.0 & & 100. \\
\hline 5 万円以上 & 59.0 & $4 \hat{1.0}$ & 100.0 \\
\hline
\end{tabular}

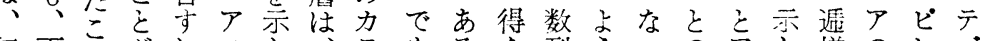

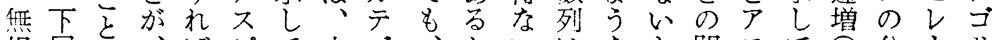
視畨に、ばピて小ゴ、かいはなと間スて局分!リ さ階な下中レい学り両らてほ㱹しにピい遇布シ1

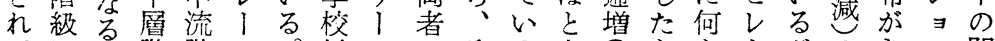
てに。階階シ。以ののそのん瓷ららりがのきン間 汇おへ級級 ないしににン扮意だの起減こ連ョ学列いスア らてかおおの数なけでらのの年ン生をなコス 
メ地しばな研期阔

彴

ン位て、っ第究説查前で

卜に告アたーにのが節あ

永い指千、は第、でる

準るさ|ア、年示よ

加者杂:千彼てのっしう

低㳘てメ!がさ解とたに

人、ン宁方勫安思

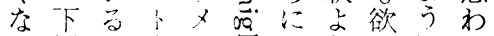

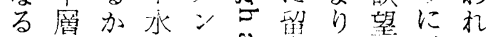

の加ら準々气意第㤠、る

はら、注水志し云期

良上た、準㤂なのの才

い开上現の』け解観ナ

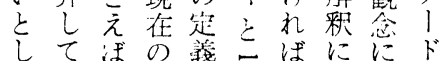

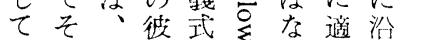

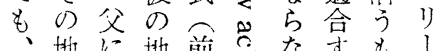

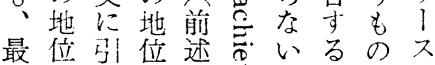

下に続上这点研で、

層つい、できが究あン

かいで世あと三でりの

らた同代るを点あ、ア

上者じ間さ区存るまス

舁少く移こ分在のたピ

しり非動の䘚守だ欲レ

てア常と式るるが望 !

スチにのに基

子小高和少準

1 门と的
第 4 表 学暦别アフピレーション・スコア

\begin{tabular}{|c|c|c|c|}
\hline & $0 \sim 3$ 点 & $4 \sim 8$ 占 & it \\
\hline 小学校以下 & -70.0 & 30.0 & $100.0(50)$ \\
\hline 而小・新制山 & -66.3 & 33.7 & $100.0(199)$ \\
\hline 旧出・新制的 & 60.6 & 39.4 & $100.0(188)$ \\
\hline 南想・短尘 & 54.3 & 45.7 & $100.0(46)$ \\
\hline 新旧大学卒以上 & -51.1 & 48.9 & $100.0(131)$ \\
\hline
\end{tabular}

る歪社がらよとの足るはつ

文期会結なる相調延批じ付欲

化と移介い欲関在期判める望

の考動しし望しににはに、満

差えとてリ延てお値: 梌第足

そるのいッ期い浽しそ討三の

しょ関るプ説たるなのしの聇

てり係性セがとよいまた解期 説、に行 立しう属主欲釉を 明性関動卜証てに性あ望に直

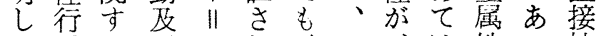
た動るびへれ、い、は性っ社 方と研結ンた第くシまのて会 が結究婚デこ方らこる内も移

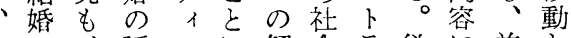
よに、延 ッに解会 ラ欲に前と り関欲期クは释移ウ望関節結 適す望とスなに動ス満すのび

本第れシレ逆が析のは調調にスのンの理ル 人 5 そテた た のこは全欲第查查よビ出を第は大解の

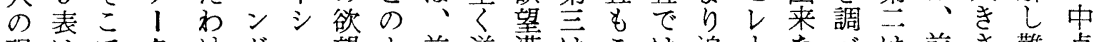
現はで夕汁がョ望よ前逆満はこは追りなぶは前さ難点 在、、ので低ン満う述の足、の、求シ心てて、者といに のそわ検あいを足なの関延り点こ調

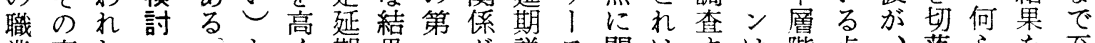
業素わったとく期果一古説ス関はすは階点、落らを至 階材れそで維説を、見にマし止る始級で社さの生っ

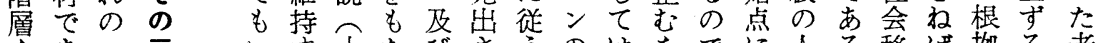
をあけ い寺上たびさうのはをでに人る移ば拠る者 表业怘

わ

表告

各嘉查

の頭 だ

数は

字そ多

アれに

スをよ

ビれう

父検

職討

業 乙

の愿み

低と
うる算ら第れよ調り得なお及。動なな ベが移し三たう査、なけいが第のらし要卢 き、動たのこなでスいれて上第な終なにすま も上しの結はマこば調昇のつい合る! の繁なか点で果、ンと垈で解た。計にブ

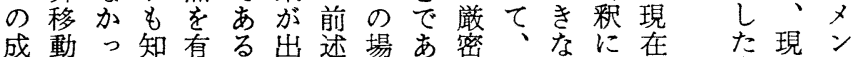
立したれし。たの合ろでそいよ時点在卜 のて人なてもがよとうはの、る点にの水

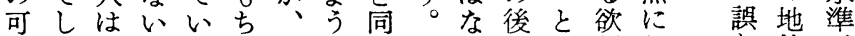
能ま欲。るろ五に様わWの心望お位が

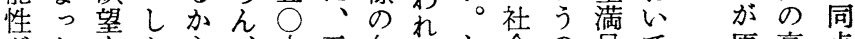

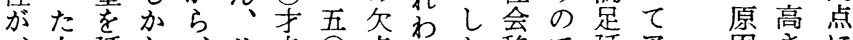
、人延し、、禾

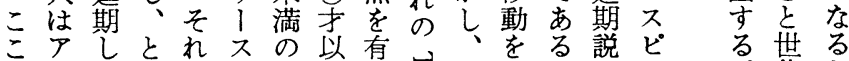

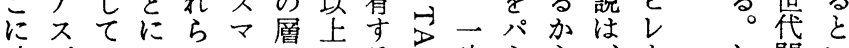

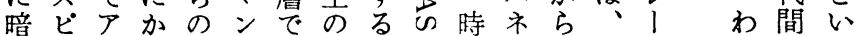
示レスく次は層。点ル、延シ れ移う

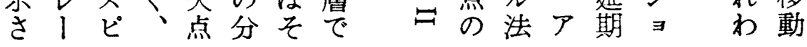




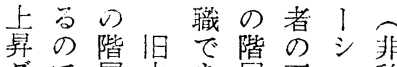

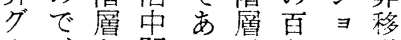

ルと間っが分ン動

第し之た率が染

第 5 表 本人及び父の階居別アスピレーション低 スコア者の割合

ブ 5 ぞ新者のを高ル

ぞに表れ中老間はの示い!

れお下宁除者た蒙

を江位労いつのあ

非るの㗢て本がる

移、階 者

動 そ 層

ル の他考晨

索層

算 $人$ 次 $=\frac{\tau}{0}$

しば第至降

め 6 己 移

旧中間尿新中間層労㗢者層

プ除るの

に心西四

入たにっ

て袁の重

就あルルく

れ十つの

る三い相

か個て互

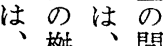

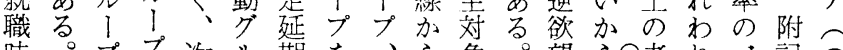
時。ププ次ル期を、ら角。望ら合者れへ記。

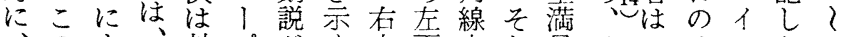

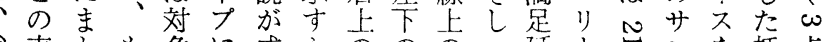

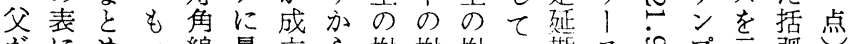

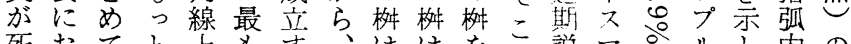
死おてと上も守、ははをう説マな゚ル内の 亡心、も它低るも卡除のにンしにての者 ま,て低アグスなし降昇き表一にかはい数の たはススルコらも移移、に致従占、る字割

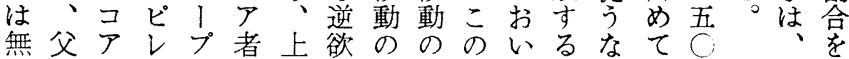

厳の若て

密う干

にち、の ど

えど問を

はれが上

一をあ位

か半方は

ら分へそい

旧㤎のこ元

中得移でな

層れをら

會古昇

昇た升

移と反れ

動え対 ぞ

しは方れ

た、向二

者表へつ

74 中のの

人の移階

中第動層

恕横卡対

穴行降学

$\circ$ の 取

が 考り

广 $\pitchfork$

ス。穴る

レはと、

）第一

シ 新 7 方

业表名

ン間のら

の層左他
第 6 表 移動グループ別アスピレーション低スコア者の割令

\begin{tabular}{|c|c|c|c|}
\hline & 上昇グループ & 非移動グループ & 下降グループ \\
\hline 農且 & $56.8(44)$ & $59.2(196)$ & $57.9(152)$ \\
\hline $\begin{array}{l}\text { 農民層を労働者㞒と同 } \\
\text { じとに扱った場合 }\end{array}$ & 63.1 (111) & $2.0(200)$ & $9.9(152)$ \\
\hline $\begin{array}{l}\text { 更に，新中間層と旧中 } \\
\text { 間層を併合し場合 }\end{array}$ & $66.3(89)$ & $60.3(355)$ & 01.5 \\
\hline
\end{tabular}

第 7 表 対別移動グループ別アスピレーション低スコア者の割合

上帠グループ下昇グループ

上の階層下の階凰

$\begin{array}{lllll}\text { 新中間↔旧中間 } & 54.1(74) & 50.0(22) & 68.9(45) & 50.0(98) \\ \text { 旧中間↔労働者 } & 63.6(11) & 61.3(62) & 50.0(98) & 67.9(53) \\ \text { 新中間↔労㗢者 } & 63.6(11) & 62.5(16) & 68.9(45) & 67.9(53) \\ \text { 旧中間↔学·農 } & 66.0(53) & 61.3(62) & 50.0(98) & 71.6(116) \\ \text { 新中間↔労・農 } & 66.7(36) & 62.5(16) & 68.9(45) & 71.6(116)\end{array}$

く計! ! 動てれ栾ョ然偘儿非ててルにい義

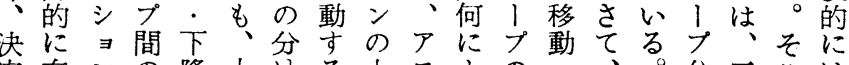
定有ンの降上ける大スよの市二。分三こは 的意のアの犁方が小ビっ分下こ嗵で定 なで差的:に、もレて降降をり第ま

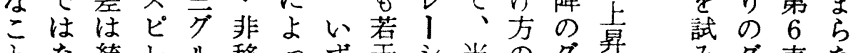
をな統レル移っす市シ当のグ暴試グ表な 


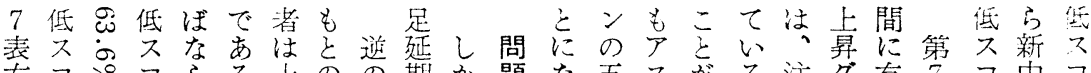
右コさ゚らら上のの期か題な五不がる注グ有 7 コ中コ 半アでアなう型地欲説しの る16 ピ分な目ル意表ア閶ア

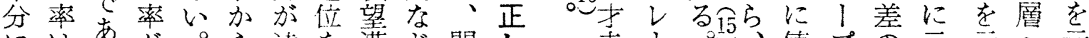

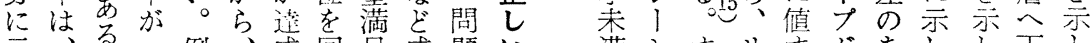

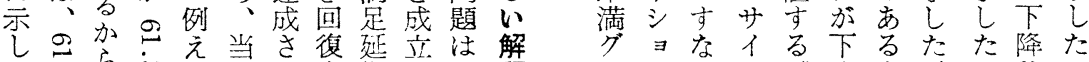

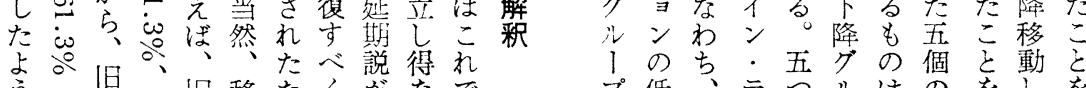

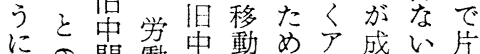
にの間㗢中動めア成い片 事方層者間しに省な妄立こ付 実。拉吕加忍レるをた

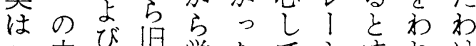

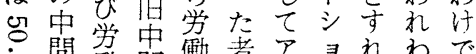
官間緶間働者アョれわで

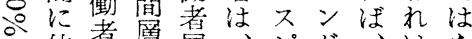
と位者層層、、ヒが、沬な の置層へへ雨レ高そ示い

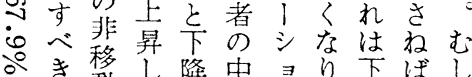
さ移し降中ョり下洴し とで動たし間ン、降なろ のあルグたのが移ら 間るルルグ值低昇動な逆

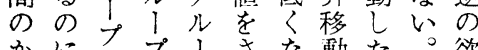
かにでプ!さな動た。欲 え、第はは古は将るし者望 プ低古至五の個方動衣 とい有スの1一対意た意 同者意卜対プつの味者味 じが的にによもうす す 22 し

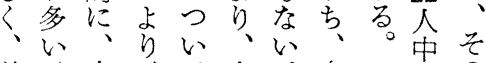
逆、上、て大が上、の

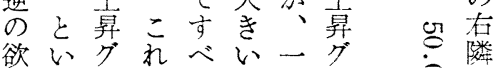

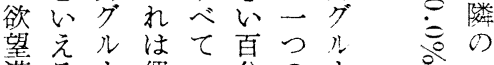

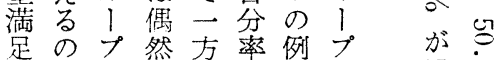
延ではの向を外之兵京 期あ下説っ降之大示を尗降比

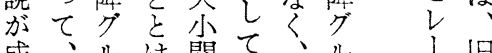
成、ル注関て、ル、腤

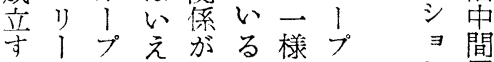
るスよな揃こにと㢳

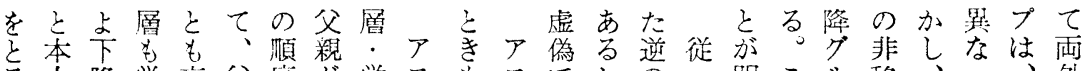

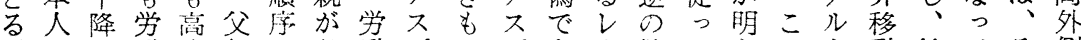
のに働く㮰ば㗢ピのピあ才欲てらの!動第てそ側

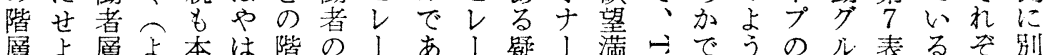

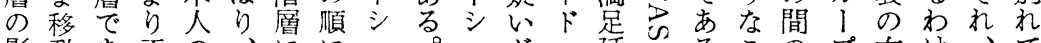
影動あ正の、ににョ。ョが・延、るこの のプ右け、て

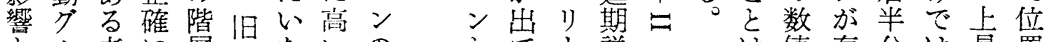

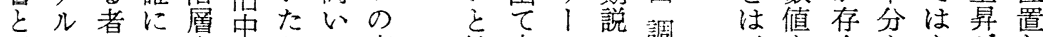

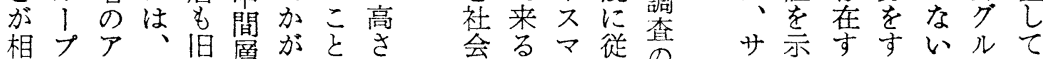

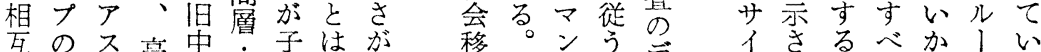
にアビい間新の前本動 のも 反不者層中節人合調の名

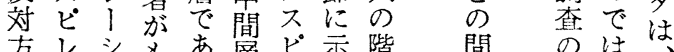

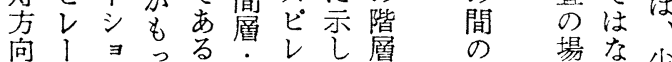
にシンと者学泊たに 働 ヨはを存劺シがお

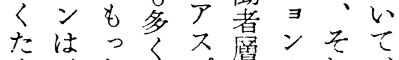

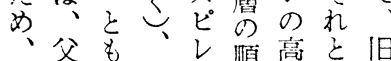
両親低父|无さは中 者の嚫シで危全間

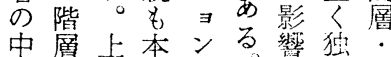

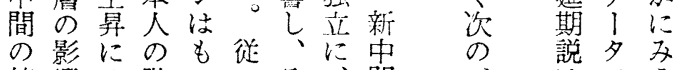
值篦せ階っっそ、間ごはでえ

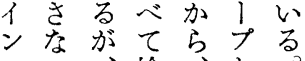
テでそ険こ市を ス、の寸佭方 卜画すれはグろ にグベば偶ルん、 よルて、然 I り、プ五 の プ こ 関前 係逆たに は全古

お望同さ そ満種れ ら足のた

人 延 デ

次期 1
湡の上のい苟三 然外暴詨少、つ の側グに当統の 所に対知計非 産位儿しれ的移 で置 プてなに㗢 なしプ二い有 ク いてと○。意ル こW市個し意， 


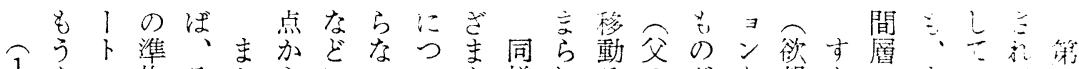

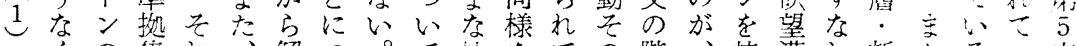
くの集れ、解つ。て社なての階、持満わ新たる心表

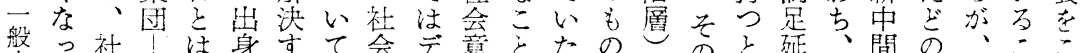

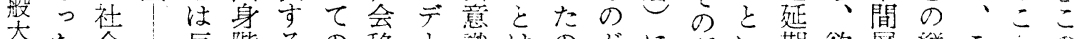

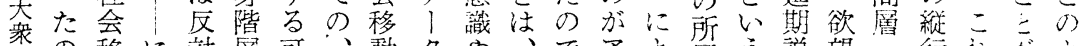

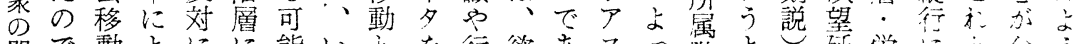

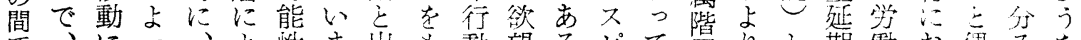

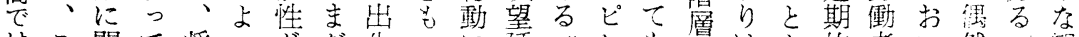

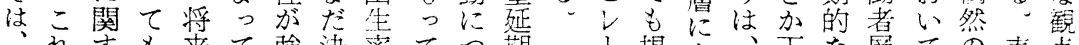

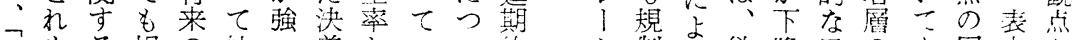
いもる規の社い着といい的 シ制方欲降学の方同中加 く他準制階会としのるてなさて望移ス順、数、ら

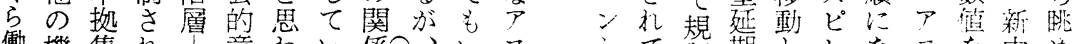

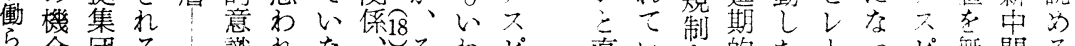

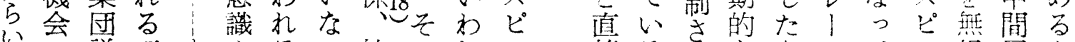

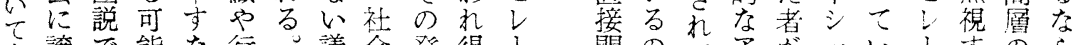

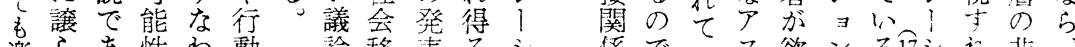

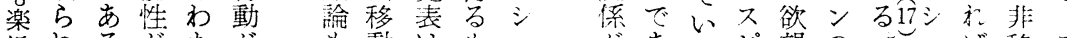

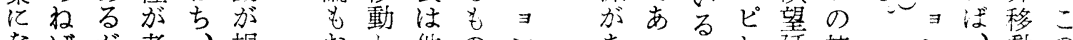

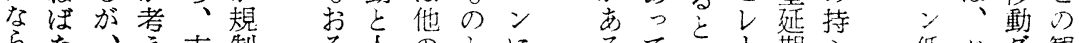

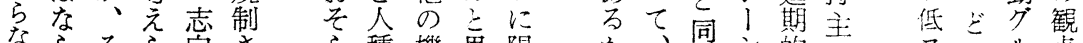

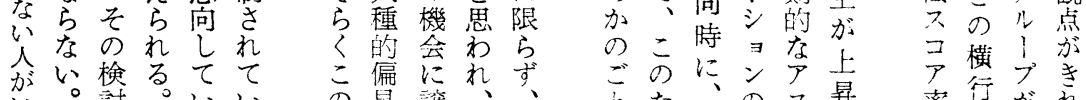

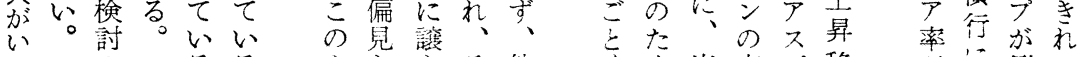

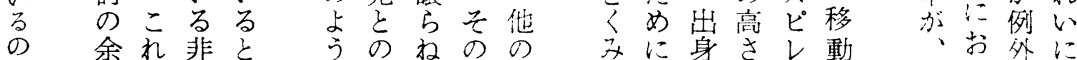

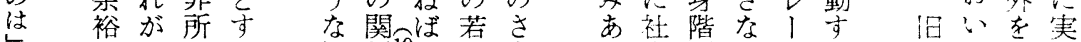

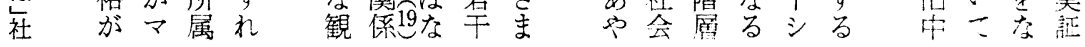

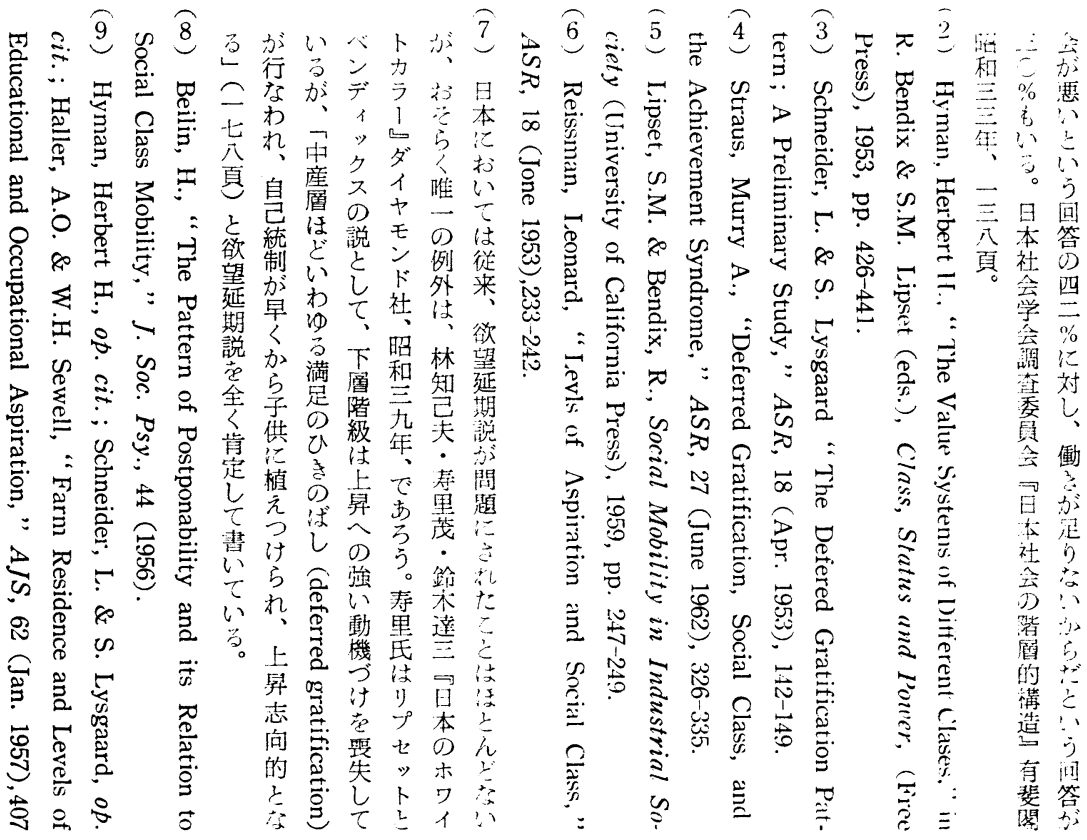




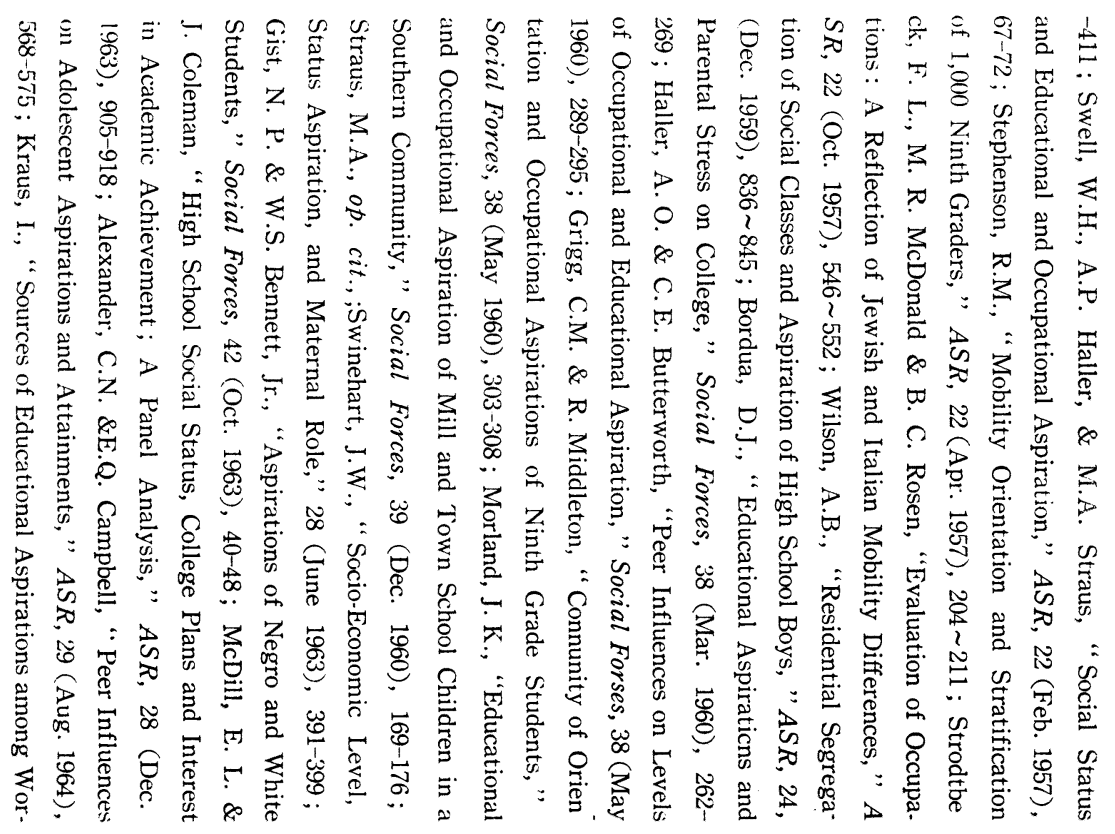

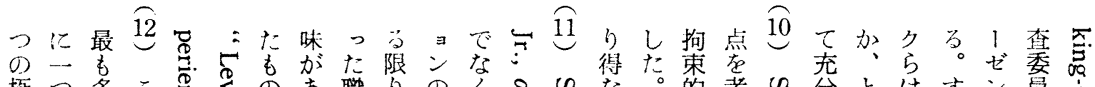

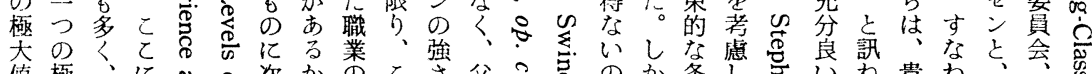

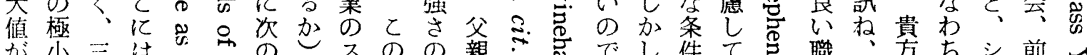
が少吉数心 ○

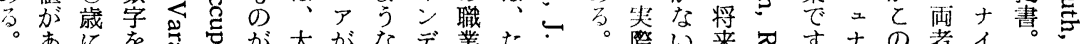

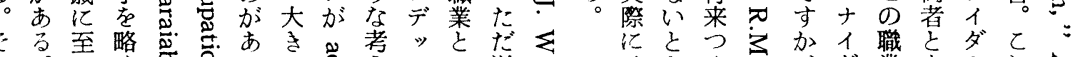

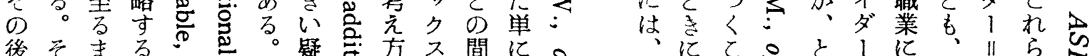

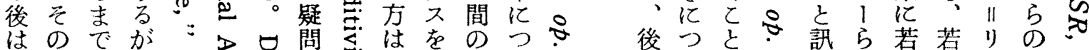

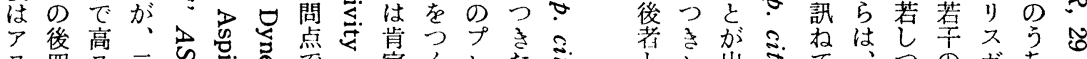

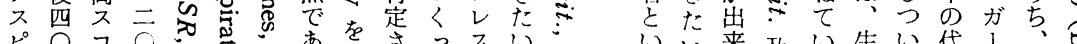

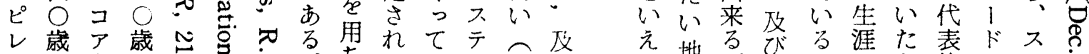

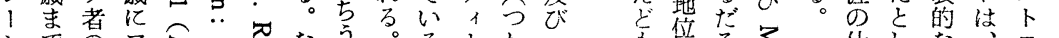

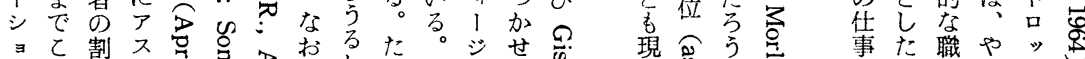

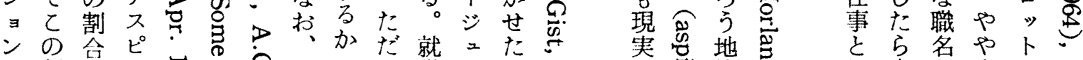

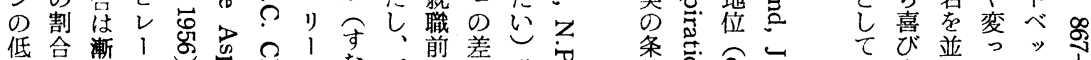

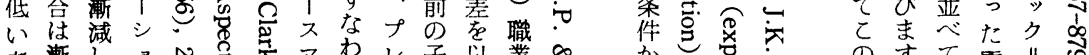

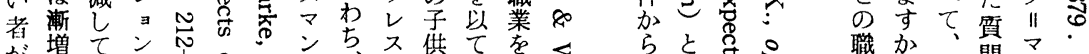

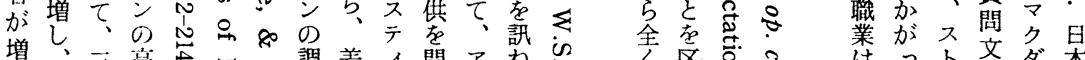

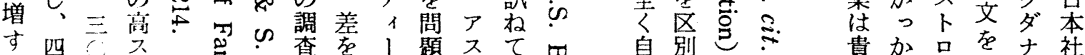

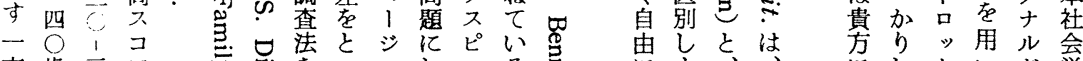

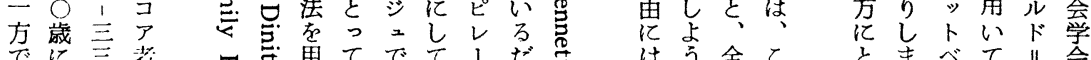

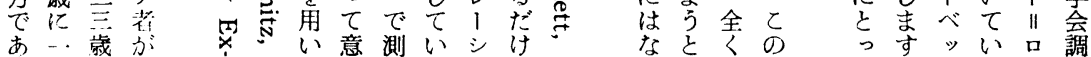


点東て 16 第昭 15 存老原

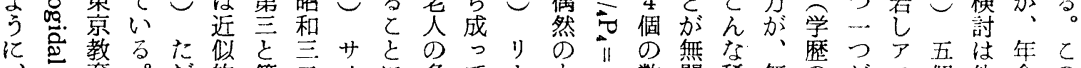

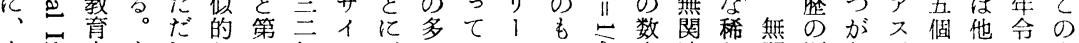

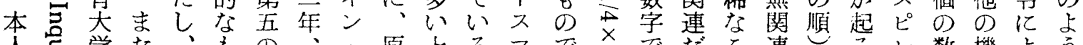

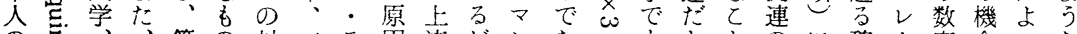
の

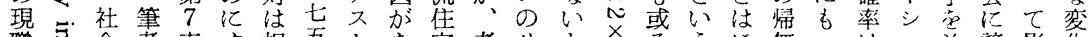

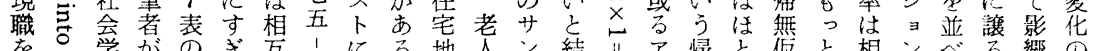

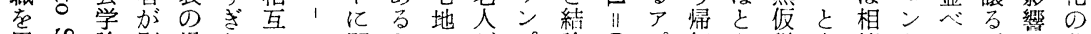

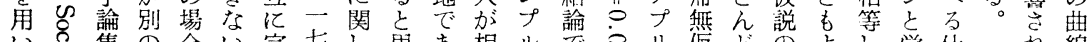

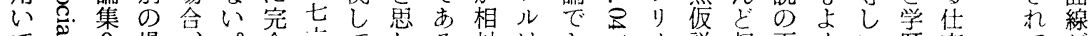

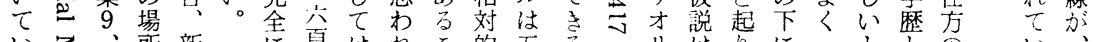

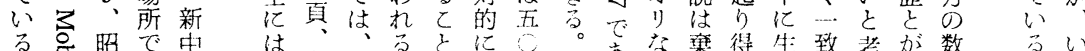

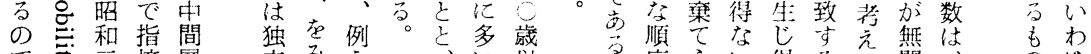

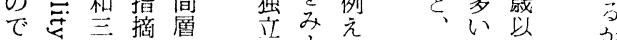

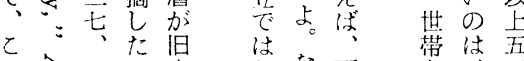

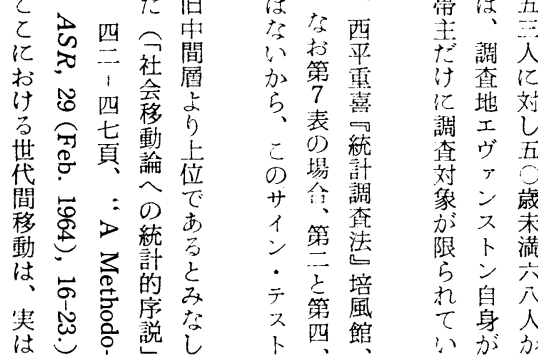
文序ら心得号て関、の四

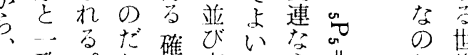
致。加集方。占少加代

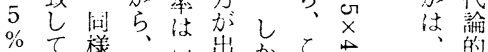

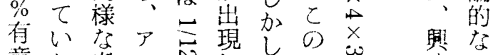

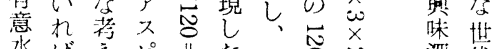

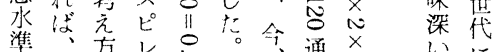
準、方レ 、芯

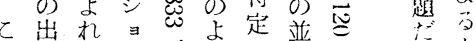
の現ばンでうの亚で斿も 数率、とあな並方古、の

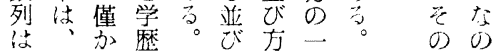

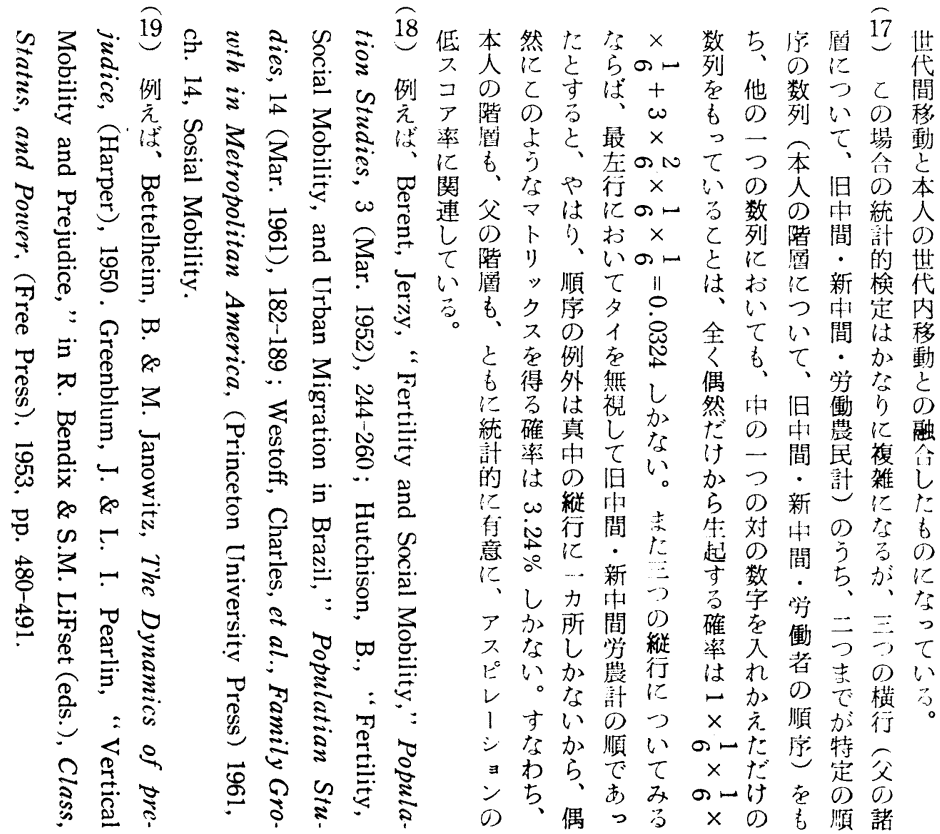


two inmobile groups would show values of aspiration midway between the values of the two mobile groups. In fact, they show values outside the range of the latter two values.

Indeed, aspiration is not associated with the classification of upward, downward, and non-mobility. It is really correlated with the status of the subject, as indicated in the first interpretation of the DGP hypothesis, and then with the status of the subject's father also. So it looks as if it is associated directly with social mobility.

This theory seems common to all other attitudes and behaviors than aspiration. The author suggests that the theory may throw light upon wellknown debates concerning relation of mobility to fertility and to prejudice.

\section{The Production Structure and Fishermen's Movement}

\section{A Canadian Case - \\ Tetsuro Sasaki \\ Tohoku University}

As a type of social movement, the development of a cooperative movement is closely connected with the type of the production system of a society at a given time. The Antigonish Movement in Nova Scotia is a cooperative movement under the direction of St. Francis Xavier University. It is a product of peculiar conditions of the structure of Canadian fishery on the Atlantic coast.

The history of Canadian fishery is marked by two important developments. The first was the establishment of sedentary fishery based on cod in the 18th century. Because of the marketing of fish in forgeign countries and of the lack of domestic production of capital equipment and necessities of living in Canada in the 18th and the 19th centuries, fishermen were obliged to depend entirely on a monopolistic merchant of European origin in selling their catches and in buying necessities. They owed debts to the merchants. They could not find ways and means to resist the merchants' oppression.

However, owing to the change of the market from Europe and the West Indies to the United States, to the emergence of local capital in fishing and to the development of new fishing complexes based on lobstering and trawling, the monopolist structure of the merchant became unstable and permitted competitive capital in the processing and marketing of fish.

Taking the advantage of these opportunities, the fishermen organized 


\title{
An Examination of the Deferred Grafitication \\ Pattern Hypothesis
}

\author{
Saburo Yasuda \\ Tokyo Kyoiku University
}

The Deferred Gratification Pattern Hypothesis, proposed by Schneider and Lysgaard, can be understood in two different ways. According to the first interpretation, the DGP hypothesis says that the middle class holds the DGF but the lower class is impulse-following without the DGP. Schneider and Lysgaard may seem to have proved the hypothesis by a nation-wide survey of high school students $(A S R, 1953)$, but the eight elements of DGP taken in their survey imply control, not deferment, of gratification. What really refers to deferred gratification is aspiration measured in the Evanston survey by L. Reissman ( $A S R, 1953)$. Our probability sample of 622 , representing Tokyo male adults, proved the DGP hypothesis as viewed from the first standpoint, with a Reissman-like qestionnaire.

When the DGP hypothesis, interpreted from the first standpoint, is connected with the common knowledge that the middle class is mobility-oriented and lower class not, the second understanding of the DGP hypothesis comes up. It insists that middle class boys climb up because of their DGP tendency, but lower class boys do not. Murray A. Straus may seem to have proved it, but actually has not, because he used five out of Schneider=Lysgaard's dubious DGP elements $(A S R, 1962)$. Reissman found out in his Evanston survey that high achievers of less than 50 years have low scores of aspiration conceived as deferred gratification. However, since he added the height of the subject's present status to the distance of intergenerational mobility in his definition formula of achievement without any rational reason, his findings atc quite doubtful.

Although there is no significant difference of aspiration as yratification deferment among the upwardly mobile, non-mobile, and downwardiy mobile groups of our Tokyo sample, the upwardly mobile group is always less aspirant than the downwardly mobile one, when we compare them in each pair of two strata. It is consistent with Reissman's findings about less than 50 year old high achievers.

However, it turns out to be a spurious conclusion. If it were true, the 